\title{
Influence of cleansers and a \\ phytotherapic against Candida albicans on the properties of denture liners
}

\author{
Influência de limpadores e de um fitoterápico anti-Candida albicans nas \\ propriedades de reembasadores de prótese
}

Tatiana Pereira-Cenci*

Thais Nunes*

Caroline Barwaldt

Aline Moraes*

Rafael Sarkis-Onofre*

Noéli Boscato*

\section{Abstract}

Objectives: the aims of this study were to evaluate the antimicrobial activity and effect of denture cleansers and the phytotherapic Plantago australis Lam. on mechanical properties of two resilient denture liners. Materials and method: samples of acrylic and silicone based materials were submitted to biofilm formation using 24well polystyrene cell tissue culture plates to form C. albicans biofilm for 1, 7 and 14 days. The specimens were subjected to the following treatments: distilled water, $0.5 \%$ sodium hypochlorite, sodium perborate and Plantago australis Lam. Counts of Candida were calculated and the results expressed in colony forming units (CFU)/ $\mathrm{mm}^{2}$. The following analyses were performed: sorption and solubility, surface roughness and scanning electron microscopy (SEM). Results: three-way ANOVA showed a statistically significant difference between materials $(p<0.001)$ with the resin-based liner presenting higher surface roughness without difference between measurements before and after treatment (paired t-test). T-test showed no statistically significant difference for sorption $(p=0.364)$ and solubility $(p=0.278)$ for both liners. SEM analysis revealed a more irregular surface topography in the resin based denture liner after the treatment with sodium hypochlorite. Candida albicans counts were equal for sodium perborate, Plantago australis Lam. and distilled water, while sodium hypochlorite showed the lowest counts $(p<0.05)$. Conclusions: $0.5 \%$ sodium hypochlorite was the most effective cleanser.

Keywords: Dentures. Denture cleansers. Candida albicans.

\section{Introduction}

Candida albicans is one of the main pathogens responsible for the development of denture stomatitis. This disease can also be associated with other factors as the presence of biofilm, inadequate oral hygiene and the use of denture liners ${ }^{1}$. Resilient denture liners available as silicone and acrylic resin based materials are often used to fill the conventional acrylic resin base, although disadvantages related to physical and mechanical properties result in higher microbial adhesion when compared to acrylic resin ${ }^{2}$.

Brushing alone could be insufficient for controlling biofilm formation in geriatric patients, thus chemical denture cleansers should be used to achieve suitable hygiene ${ }^{3}$. Conversely, the routine use of chemical cleansers can be harmful to the resilient lining materials causing deterioration ${ }^{4}$ and creating irregularities on the surface of the prosthesis, facilitating the adherence of C. albicans ${ }^{5}$.

Sodium hypochlorite $(\mathrm{NaOCl})$ is considered the gold standard for cleaning dentures. Yet, the literature shows a variety of natural products with antifungal activity against C. albicans ${ }^{6}$. However, there are few reports evaluating the use of phytotherapics to help cleaning resilient denture liners and if these products have any influence on their properties. In this context, the phytotherapic Plantago australis 
Lam. ${ }^{7}$ has not yet been studied for the prevention of denture stomatitis or for cleaning dentures, but has been recommended ${ }^{8,9}$ for the treatment of upper respiratory tract infections and chronic bronchitis ${ }^{8}$.

Thus, the aim of this study was to evaluate the influence of chemical denture cleansers and Plantago australis Lam. on the antimicrobial activity and the surface roughness and sorption and solubility of two resilient denture liners after biofilm formation of $C$. albicans at different periods of time.

\section{Materials and method}

\section{Experimental design}

This in vitro, single-blinded (biofilm analysis) study had a completely randomized design (for all variables tested) with substratum type (two resilient denture liners) and cleansers (deionized and distilled water, $0.5 \%$ sodium hypochlorite, sodium perborate and Plantago australis Lam.) as factors under study. The study was approved by the Local Research and Ethics Committee (Protocol 084/2009). The oral health of one volunteer (saliva donor) was assessed and the participant signed a written informed consent before being accepted into the study.

The specimens of two commercially available resilient denture liners, acrylic (Soft Confort; Dencril Trade Plastics Ltda, Sao Paulo, SP, Brazil) and silicone based (Quickline; Sterngold Restorative Systems, Hamburg, Germany), were relined to acrylic resin (Clássico Artigos Odontológicos Ltd., São Paulo, SP, Brazil), and submitted to biofilm formation, using 24-well polystyrene cell tissue culture plates for biofilm formation of C. albicans for 1,7 and 14 days. Next, the specimens were subjected to the following treatments: distilled water (negative control), $0.5 \% \mathrm{NaOCl}$ (Biodinâmica, Ibiporã, SP, Brazil) (positive control), sodium perborate (Corega Tabs, Rio de Janeiro, RJ, Brazil) and Plantago australis Lam. At the different experimental periods, discs containing biofilms were aseptically removed from the wells to remove loosely adherent micro-organisms. Counts of Candida albicans were performed using a stereomicroscope and the results were expressed in colony forming units per area (CFU)/ $/ \mathrm{mm}^{2}$.

\section{Preparation of specimens}

All materials used in the experiment were manipulated according to the manufacturers recommendations. Wax discs were prepared $(10 \mathrm{~mm}$ diameter and $2 \mathrm{~mm}$ thick) and included in flasks to obtain acrylic resin specimens (Artigos Odontólogicos Classico, São Paulo, SP, Brazil). The surface area of each disc was $89.92 \mathrm{~mm}^{2}$. After preparation, the specimens of acrylic resin were relined with denture liners using a silicone-based denture liner or acrylic-based denture liner to mimic denture relining clinical condition. The specimens were subjected to cleaning for removal of contaminants by sonication (Unique, Indaiatuba, SP, Brazil) in sterile distilled and deionized water for $20 \mathrm{~min}$, before biofilm formation ${ }^{10}$.

\section{Surface roughness, sorption and solubility tests}

The following analyses of the materials were performed: sorption and solubility (pretreatment), surface roughness-Ra (pre and post treatment) and scanning electron microscopy analysis (post treatment).

Specimens' Ra (n=30) was measured before and after treatments using a profilometer (Mitutoyo SJ 201,Tokyo, Japan). Three readings were made for each specimen and mean values were calculated ${ }^{11}$.

Disc-shaped specimens $(\mathrm{n}=10)$ with $15 \mathrm{~mm}$ in diameter (D) and $2 \mathrm{~mm}$ in height (h) were prepared, stored in a desiccator at $37^{\circ} \mathrm{C}$ with silica gel and daily weighed to verify mass stabilization (dry mass, $\mathrm{m}^{1}$ ), with mass variations lower than $0.1 \mathrm{mg}$ in any $24 \mathrm{~h}$ interval. The specimens were stored in artificial saliva at $37^{\circ} \mathrm{C}$ for 7 days until mass saturation with saliva $\left(\mathrm{m}^{2}\right)$. The specimens were then placed in the desiccator again at $37^{\circ} \mathrm{C}$ and reweighed until a constant dry mass $\left(\mathrm{m}^{3}\right)$ was obtained. Weighing was performed using an analytical scale with 0.01 mg accuracy (AUW220D, Shimadzu, and Tokyo, Japan). The volume (V) of each specimen was calculated based on the following equation: $V=\pi R^{2} h$, where $\mathrm{R}$ is the specimen radius. Water sorption (WS) and solubility (SL), given in $\mu \mathrm{g} / \mathrm{mm}^{-3}$, were calculated as follows: $\mathrm{WS}=\left(\mathrm{m}^{2}-\mathrm{m}^{3}\right) / \mathrm{V} ; \mathrm{SL}=\left(\mathrm{m}^{1}-\mathrm{m}^{3}\right) / \mathrm{V}^{11}$.

\section{Reactivation of the microorganism}

A loopful of stock yeast culture of $C$. albicans ATCC 90028 was reactivated from its original culture at $-70{ }^{\circ} \mathrm{C}$ in $10 \mathrm{ml}$ of Sabouraud Dextrose medium (Sabouraud Broth; Difco, Sparks, MD, USA) and incubated for $24 \mathrm{~h}$ at $37{ }^{\circ} \mathrm{C}$ under aerobic conditions. Cells were harvested, washed with saline solution and standardized to 1 to $5 \times 10^{6}$ cells $\mathrm{mL}^{-1}$ $(0.5 \text { of the McFarland scale })^{3,4}$.

\section{Collection, centrifugation of the human saliva and formation of the acquired pellicle}

Stimulated saliva (Parafilm ${ }^{\oplus}$; American Co., Greenwich, USA) of a 24 year-old male was used to form the acquired pellicle prior to the biofilm assay. The saliva was collected at the same time and with limited volume of $50 \mathrm{~mL}$ per collection period. Inclusion criteria included any gender, normal salivary flow rate $(0.3-0.5 \mathrm{~mL} / \mathrm{min})$ and not having used antibiotics during the 3 months prior to the study, 
while poor oral hygiene, diabetes or other systemic conditions that predispose to denture stomatitis were exclusion criteria. The saliva was centrifuged (10000 g, 10 min at $4{ }^{\circ} \mathrm{C}$ ) and the supernatant was removed and immediately used. The specimens were inserted into each well followed by the addition of clarified saliva ( $1 \mathrm{~mL})$ (Bio-one; Greiner, Frickenhausen, Germany) and kept for $30 \mathrm{~min}$ to form an acquired pellicle under stirring at $37 \pm 2{ }^{\circ} \mathrm{C}$. Next, saliva was removed and discarded.

\section{Biofilm formation}

C. albicans previously grown cell suspension $(2 \mathrm{~mL})$ was added to each well. Biofilms were incubated at $37{ }^{\circ} \mathrm{C}$ under aerobic conditions for 1,7 and 14 days, according to experimental conditions: substratum type and cleansers as factors under study evaluated at different periods of time of biofilm formation. All biofilms tested were performed in duplicate in three independent experiments on different days.

\section{Treatment with chemical cleansers}

The specimens were subjected to the following treatments: distilled and deionized water, $10 \mathrm{~min}$ soaking ( negative control), $0.5 \% \mathrm{NaOCl}, 10 \mathrm{~min}$ soaking (positive control); sodium perborate, $5 \mathrm{~min}$ soaking and Plantago australis Lam., 10 min soaking ${ }^{8}$. Each sample was placed individually in sterile Falcon tubes $(50 \mathrm{~mL})$ containing $30 \mathrm{~mL}$ of one of the treatments. After the treatment period, all samples were gently washed with PBS for $15 \mathrm{~s}$ and was placed in a sterile tube containing $1 \mathrm{~mL}$ of $0.9 \%$ $\mathrm{NaCl}$ for processing.

\section{Biofilm quantification}

The suspension containing the specimen and the biofilm was vortexed for 1 minute and sonicated at $40 \mathrm{~W}$ and $5 \%$ amplitude with three pulses of $10 \mathrm{~s}$ each, serially diluted and inoculated $(20 \mathrm{uL}$ in duplicate) on specific medium (CHROMagar Can- dida). The plates were incubated at $37^{\circ} \mathrm{C}$ for $48 \mathrm{~h}$. The colony forming units (CFU) were counted and the results were expressed in $\mathrm{CFU} / \mathrm{mm}^{2}$.

\section{Scanning electron microscopy (SEM)}

In order to evaluate the changes in the surface topography of the lining materials after treatment with the cleansers, extra specimens were prepared for each treatment and materials $(\mathrm{n}=1)$ and images of SEM (SSX-550; Shimadzu, Tokyo, Japan) were obtained for each time period (1, 7 and 14 days). Samples were fixed with $2.5 \%$ glutaraldehyde for up to $12 \mathrm{~h}$ at $4{ }^{\circ} \mathrm{C}$ and then washed three times in $0.1 \mathrm{M}$ phosphate buffer at $4{ }^{\circ} \mathrm{C}(\mathrm{pH} 7.3)$ for $10 \mathrm{~min}$ each. After fixation all samples were dehydrated further in an ethanol/water mixture of $50 \%, 70 \%$, $80 \%, 90 \%, 95 \%$ and $100 \%$ for 20 min each. Finally, the dehydration in $100 \%$ ethanol was done. Samples were sputter-coated with gold (SDC 050; Balzers Union, Walluf, Germany) and examined at a 20 $\mathrm{kV}$ accelerating voltage.

\section{Statistical Analysis}

Statistical analyses were done using SigmaStat 3.5 software (Systat, Richmond, USA) employing a significance level fixed at $5 \%$. Ra was analyzed by three-way ANOVA followed by Student-Newman-Keuls and paired t-test for comparisons before and after treatment. Sorption and solubility data and CFU counts (transformed by rank) were analyzed using t-test and three-way ANOVA and SNK, respectively.

\section{Results}

Table 1 shows mean and standard deviation for sorption and solubility according to the material tested. T-test showed no statistically significant differences for sorption $(\mathrm{p}=0.364)$ and solubility $(p=0.278)$ for both denture liners tested.

Table 1 - Water sorption and solubility values according to material tested in $\mu \mathrm{g} / \mathrm{mm}^{3}$ (Mean $\pm S D$ )

\begin{tabular}{l|c|c|c|c}
\hline \multicolumn{1}{c|}{ Material } & $\mathrm{n}$ & Sorption & Solubility \\
\hline Silicone & 10 & $5.12 \times 10^{-3} \pm 1.62 \times 10^{-3} \mathrm{~A}$ & $5.12 \times 10^{-3} \pm 1.62 \times 10^{-3} \mathrm{~A}$ & 0.364 \\
\hline Acrylic & 10 & $3.33 \times 10^{-3} \pm 1.05 \times 10^{-3} \mathrm{~A}$ & $3.53 \times 10^{-3} \pm 1.12 \times 10^{-3} \mathrm{~A}$ & 0.278 \\
\hline
\end{tabular}

Same upper case letters represent no statistically significant differences among materials (t-test $p>0.05$ ).

Table 2 shows mean and standard deviation for $\mathrm{Ra}$ according to substratum type, treatment and time period. The results showed a statistically significant difference between materials $(p<0.001)$, with the acrylic-based denture liner presenting the highest Ra. Paired t-test showed no statistically significant difference between measurements before and after treatments ( $p>0.05)$. 
Table 2 - Surface roughness $(\mu \mathrm{m})$ according to substratum type, treatment and time (Mean $\pm S D)$

\begin{tabular}{|c|c|c|c|c|c|c|c|c|c|}
\hline & & \multicolumn{2}{|c|}{$\mathrm{H}_{2} \mathrm{O}$} & \multicolumn{2}{|c|}{ Sodium Perborate } & \multicolumn{2}{|c|}{$0.5 \% \mathrm{NaOCl}$} & \multicolumn{2}{|c|}{ Plantago australis Lam. } \\
\hline & & Before & After & Before & After & Before & After & Before & After \\
\hline \multirow{3}{*}{ Silicone } & $1 d$ & $1.2 \pm 0.3^{\mathrm{A}}$ & $1.5 \pm 0.5^{\mathrm{A}}$ & $1.4 \pm 0.5^{\mathrm{A}}$ & $1.2 \pm 0.6^{\mathrm{A}}$ & $1.3 \pm 0.4^{\mathrm{A}}$ & $1.3 \pm 0.4^{\mathrm{A}}$ & $1.6 \pm 0.7^{\mathrm{A}}$ & $1.2 \pm 0.3^{\mathrm{A}}$ \\
\hline & $7 d$ & $1.5 \pm 0.3^{\mathrm{A}}$ & $1.5 \pm 0.3^{\mathrm{A}}$ & $1.6 \pm 0.5^{\mathrm{A}}$ & $1.4 \pm 0.6^{\mathrm{A}}$ & $1.5 \pm 0.6^{\mathrm{A}}$ & $1.5 \pm 0.6^{\mathrm{A}}$ & $1.5 \pm 0.5^{\mathrm{A}}$ & $1.2 \pm 0.5^{\mathrm{A}}$ \\
\hline & $14 d$ & $1.0 \pm 0.2^{\mathrm{A}}$ & $1.4 \pm 0.3^{\mathrm{A}}$ & $1.6 \pm 0.6^{\mathrm{A}}$ & $1.4 \pm 0.5^{\mathrm{A}}$ & $3.5 \pm 1.9^{A}$ & $3.5 \pm 1.9^{\mathrm{A}}$ & $1.1 \pm 0.3^{\mathrm{A}}$ & $1.2 \pm 0.4^{\mathrm{A}}$ \\
\hline \multirow{3}{*}{ Acrylic } & $1 d$ & $2.2 \pm 0.6^{B}$ & $2.3 \pm 0.2^{\text {в }}$ & $2.3 \pm 1.6^{\mathrm{B}}$ & $2.7 \pm 2.1^{\text {в }}$ & $3.2 \pm 1.5^{\text {в }}$ & $3.2 \pm 0.6^{B}$ & $2.0 \pm 0.8^{B}$ & $2.2 \pm 0.6^{B}$ \\
\hline & $7 d$ & $2.2 \pm 0.4^{\text {в }}$ & $2.0 \pm 0.6^{\mathrm{B}}$ & $2.0 \pm 1.0^{\mathrm{B}}$ & $3.6 \pm 1.6^{\mathrm{B}}$ & $2.3 \pm 1.2^{\text {в }}$ & $3.1 \pm 1.5^{\text {в }}$ & $2.2 \pm 1.1^{\text {в }}$ & $3.0 \pm 1.3^{\mathrm{B}}$ \\
\hline & $14 d$ & $2.2 \pm 0.8^{\mathrm{B}}$ & $2.8 \pm 0.7^{\text {в }}$ & $1.9 \pm 0.7^{\text {в }}$ & $2.2 \pm 1.1^{\text {B }}$ & $2.4 \pm 1.1^{\text {B }}$ & $3.3 \pm 1.0^{\mathrm{B}}$ & $2.2 \pm 1.2^{\text {в }}$ & $2.4 \pm 0.7^{\text {в }}$ \\
\hline
\end{tabular}

There were no differences between measurements before and after treatments (paired t-test $p>0.05$ ). (paired t-test $p>0.05$ ). Different upper case letters represent statistically significant differences among materials (three-way ANOVA and Student-Newman-Keuls, $p<0.001$ ).

The mean values obtained from the biofilms in the 3 time periods were analyzed, Table 3 . Student-Newman-Keuls test $(\mathrm{p}<0.001)$ showed statistically significant differences among treatments for both denture liners tested and between materials and periods. The treatment with sodium perborate, Plantago australis Lam. and distilled water were equal and different from $\mathrm{NaOCl}$, the latter totally eliminating C. albicans biofilm. When the materials were evaluated, on the $1^{\text {st }}$ day the silicone based-materials showed a higher (statistically significant) biofilm formation of Candida than the $7^{\text {th }}$ and $14^{\text {th }}$ days, however there was no difference between the $7^{\text {th }}$ and $14^{\text {th }}$ days. The resilient acrylic based denture liner showed no statistically significant difference among time periods.

Table 3 - Mean $(S D)$ counts of $C$. albicans

\begin{tabular}{|c|c|c|c|}
\hline \multirow{2}{*}{ Time } & \multirow{2}{*}{ Treatments } & \multicolumn{2}{|c|}{ Materials } \\
\hline & & Silicone & Acrylic \\
\hline \multirow{4}{*}{$1 d$} & Sodium Perborate & $1.72(3) \times 10^{5} \mathrm{Aa}$ & $0.1(0.1) \times 10^{5} \mathrm{Aa}$ \\
\hline & $0.5 \% \mathrm{NaOCl}$ & $0(0) \mathrm{Ba}$ & $0(0) \mathrm{Ba}$ \\
\hline & Plantago australis Lam. & $18.8(28.5) \times 10^{5} \mathrm{Aa}$ & $0.6(0.9) \times 10^{5} \mathrm{Aa}$ \\
\hline & $\mathrm{H}_{2} \mathrm{O}$ & $2.6(3) \times 10^{5} \mathrm{Aa}$ & $0.5(0.6) \times 10^{5} \mathrm{Aa}$ \\
\hline \multirow{4}{*}{$7 d$} & Sodium Perborate & $72.7(143.9) \times 10^{5} \mathrm{Ab}$ & $1.1(2) \times 10^{5} \mathrm{Aa}$ \\
\hline & $0.5 \% \mathrm{NaOCl}$ & $0(0) \mathrm{Bb}$ & $0(0) \mathrm{Ba}$ \\
\hline & P. major & $5.4(7) \times 10^{5} \mathrm{Ab}$ & $0.1(0.3) \times 10^{5} \mathrm{Aa}$ \\
\hline & $\mathrm{H}_{2} \mathrm{O}$ & $175.5(277.6) \times 10^{5} \mathrm{Ab}$ & $2.4(5.7) \times 10^{5} \mathrm{Aa}$ \\
\hline \multirow{4}{*}{$14 d$} & Sodium Perborate & $28(38.9) \times 10^{5} \mathrm{Ab}$ & $0.2(0.3) \times 10^{5} \mathrm{Aa}$ \\
\hline & $0.5 \% \mathrm{NaOCl}$ & $0(0) \mathrm{Bb}$ & $\mathrm{O}(0) \mathrm{Ba}$ \\
\hline & Plantago australis Lam. & $7.6(8.8) \times 10^{5} \mathrm{Ab}$ & $0.4(0.3) \times 10^{5} \mathrm{Aa}$ \\
\hline & $\mathrm{H}_{2} \mathrm{O}$ & $35(42.3) \times 10^{5} \mathrm{Ab}$ & $0.4(0.3) \times 10^{5} \mathrm{Aa}$ \\
\hline
\end{tabular}

Read vertically: upper case letters represent statistically significant differences among treatments within the same material; lower case letters represent statistically significant differences among time periods within the same material; materials where different for all time periods tested (three-way ANOVA followed by SNK, $p<0.001$.

Qualitative assessment of the samples with SEM showed different degrees of surface irregularities. Large amounts of porosities and irregularities were observed in the acrylic resin based material. In both materials tested, SEM images showed that the tested denture cleansers sodium perborate (Fig. 1 and 4) and $0.5 \% \mathrm{NaOCl}$ (Fig. 2 and 5) originated more damage on topography of the surface than Plantago australis Lam. (Fig. 3 and 6). 


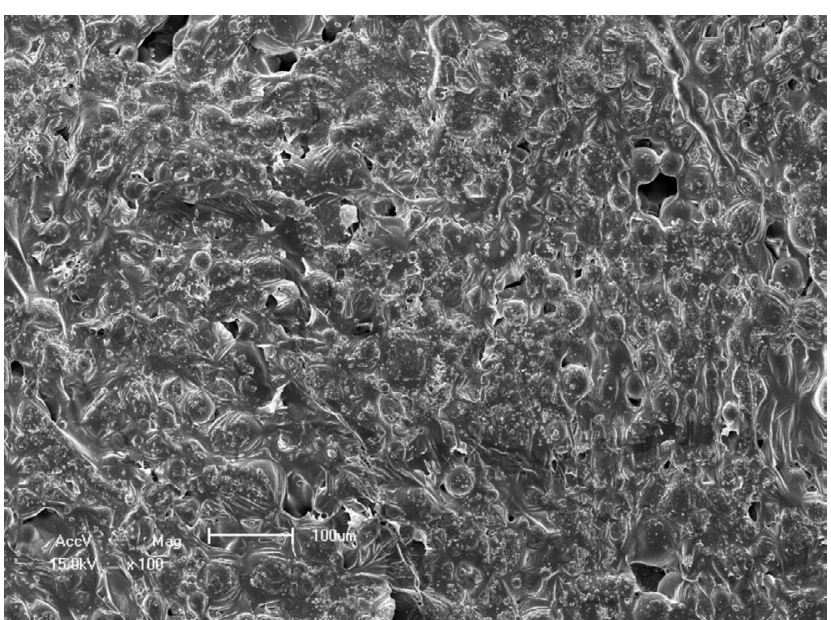

Figure 1 - SEM image of the surface of acrylic resin based denture liner tested with sodium perborate (day $14, \times 100$ )

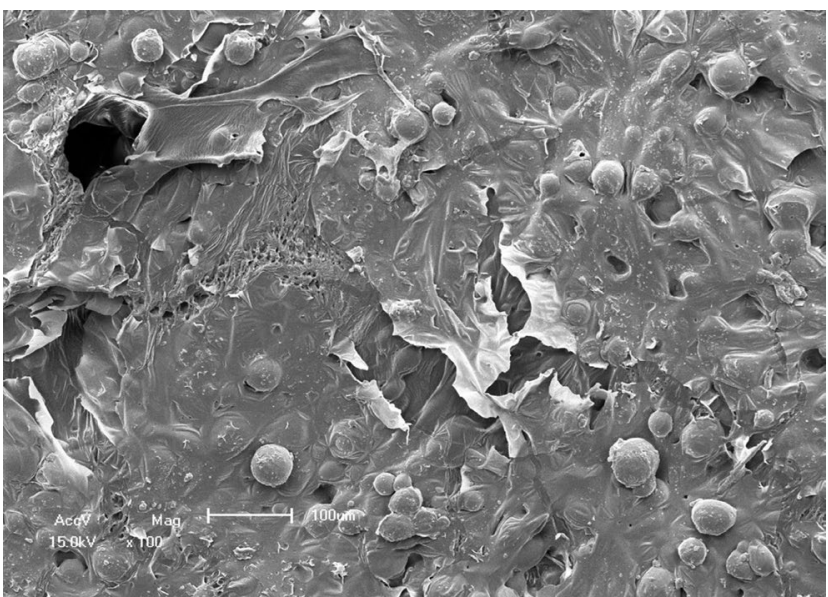

Figure 2 - SEM image of the surface of acrylic resin based denture liner tested with $0.5 \% \mathrm{NaOCl}$ (day $14, \times 100$ )

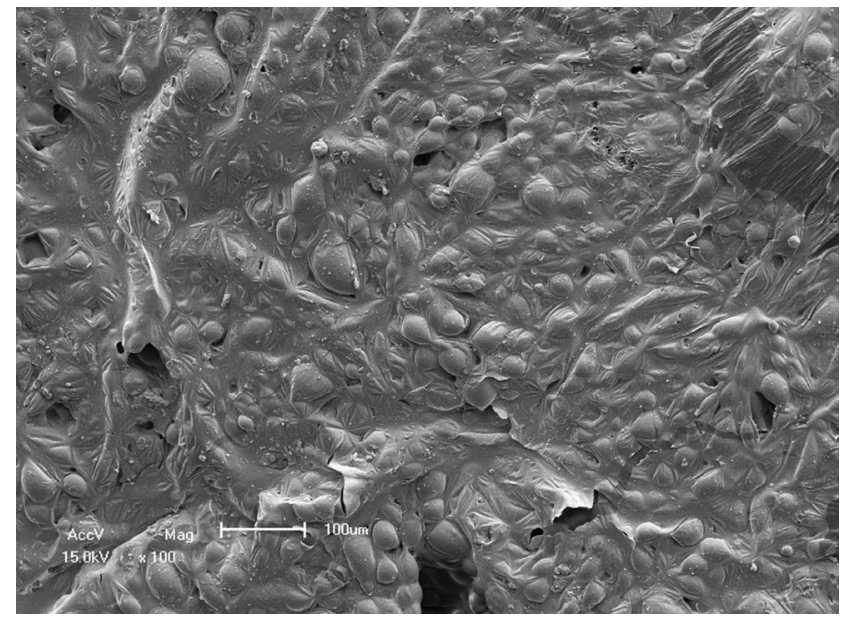

Figure 3 - SEM image of the surface of acrylic resin based denture liner tested with Plantago australis Lam. (day 14, ×100)

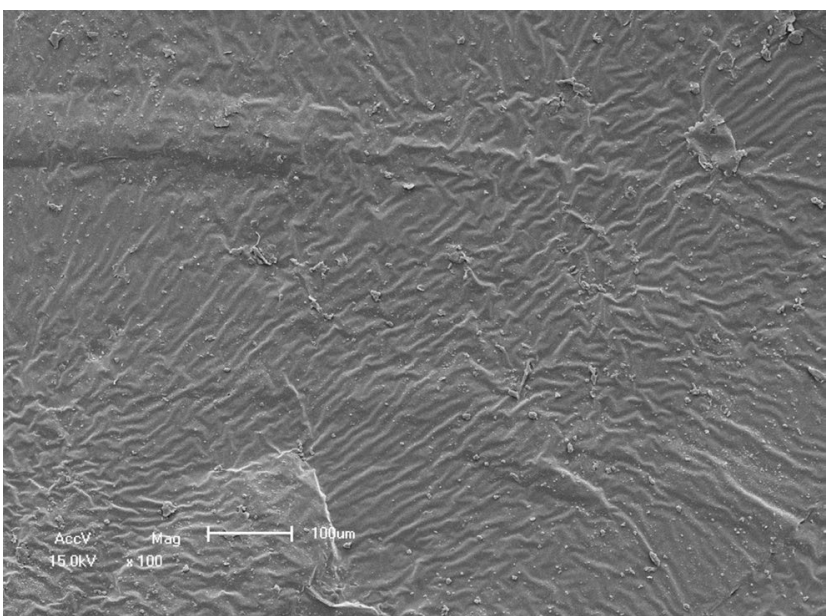

Figure 4 - SEM image of the surface of silicone-based denture liner tested with sodium perborate (day $14, \times 100)$

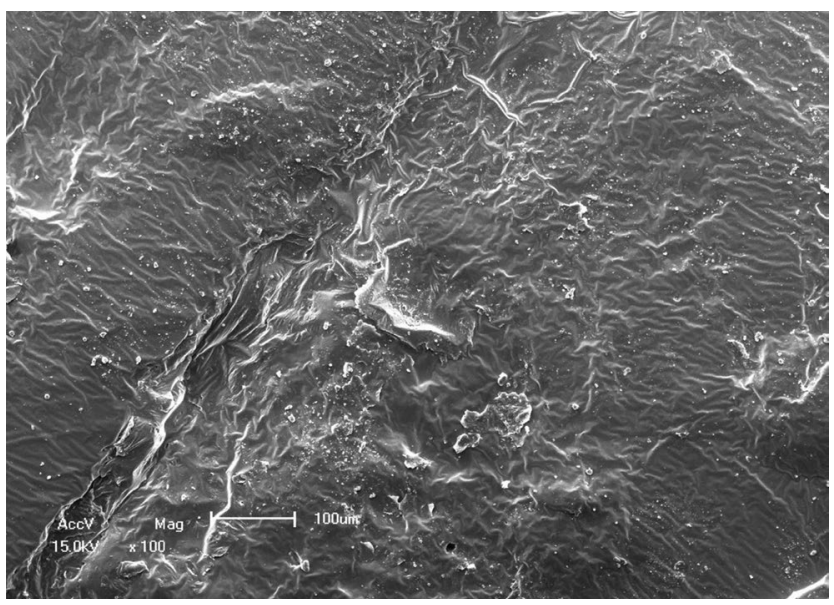

Figure 5 - SEM image of the surface of silicone-based denture liner tested with $0.5 \% \mathrm{NaOCl}($ day $14, \times 100)$

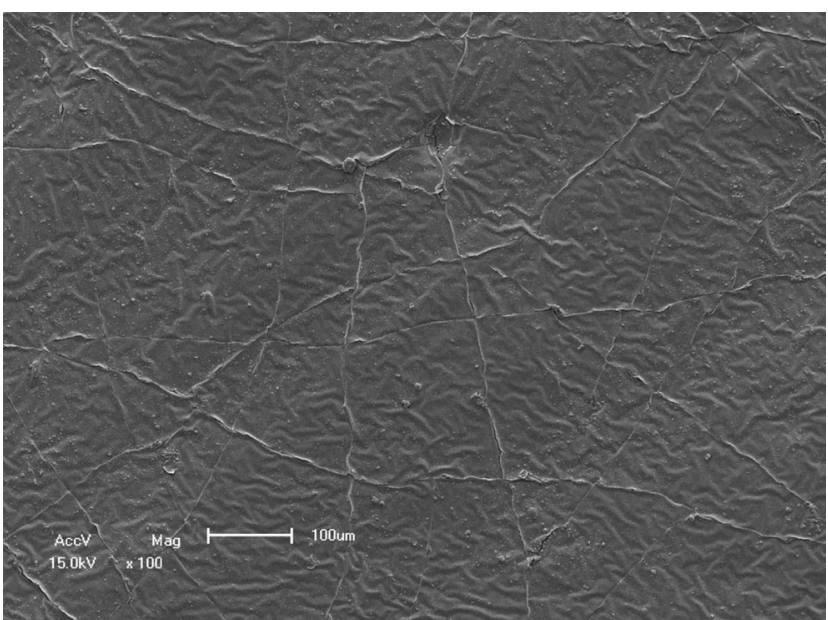

Figure 6 - SEM image of the surface of silicone-based denture liner tested with Plantago australis Lam. (day 14, ×100) 


\section{Discussion}

Our study was the first to assess both the antimicrobial effect and the surface possible changes of resilient denture liners using different treatment protocols. The immersion of dentures on chemical cleansers is considered an efficient way to clean and control biofilm formation when associated to mechanical cleansing. However, it seems that chemical cleansers have a harmful effect on the surface of denture liners ${ }^{12}$. Thus, the use of phytotherapic as denture cleanser could be an alternative method to overcome this issue. In this context, the mechanical properties assessment is important since higher $\mathrm{Ra}$ could result in higher biofilm formation, consequently increasing the potential to develop biofilm-based diseases and it is usually not tested in microbiological studies ${ }^{6,13}$.

In this study, Ra was not affected by the treatments, although there are reports in the literature showing damage caused by $\mathrm{NaOCl}^{14}$. However, Na$\mathrm{OCl}$ was used in a low concentration $(0.5 \%)$, which seems to present no detrimental effect on resilient denture liners. ${ }^{15,16}$ This result is important since this concentration may result in adequate control of biofilm formation without alteration the original characteristics of the denture liners. However, it is worth saying that in this study, the effects on the assessed properties of resilient liners were tested only for 14 days and this may have influenced the results, especially considering that other liners may be used for longer periods.

Additionally, our results showed differences between the materials. The acrylic based denture liner showed the highest roughness, as previously shown ${ }^{17}$. These differences should be taken into account after longer periods of clinical service, which could possibly result in changes in several properties of the material and microbiological composition of the biofilm ${ }^{17}$. SEM analyses revealed that the acrylic based material showed the greatest amount of surface irregularities, confirming Ra test results. SEM analysis showed higher damages on the surface materials when sodium perborate and $0.5 \%$ $\mathrm{NaOCl}$ were used, as previously demonstrated ${ }^{12,14}$.

No differences among groups were observed considering sorption and solubility tests, suggesting that the materials tested appear to have the same performance before and after the treatments, as observed in other studies ${ }^{11}$. These properties have been tested to predict clinical behavior and the longevity of the prosthetic materials ${ }^{18}$ since these materials can absorb water or lose soluble components, depending on their composition and the solution in which they are immersed.

C. albicans counts were affected by the composition of the material evaluated. The silicone based material showed higher biofilm formation, suggesting that factors as material's composition and vis- cosity, ageing and fluids of the host could influence the interaction among substratum surfaces, Candi$d a$ and biofilm formation ${ }^{19}$, since the denture liner that showed higher biofilm formation was not the same material that presented higher initial Ra. Thus, 14-day analysis showed similar changes in the different surfaces. However, the results should be taken together with the microbiological results that indicate the silicone based material as the one with higher biofilm formation.

According to our results, the treatment with sodium perborate, Plantago australis Lam. and distilled water were equal and different from Na$\mathrm{OCl}$, with the latter totally eliminating $C$. albicans biofilm. Plantago australis Lam. exposure time and concentration $^{8}$ may have been one of the reasons which the phytoterapic did not show better results with respect to the count of biofilms of Candida while this happened in previous studies ${ }^{8,9}$. However, these results should be interpreted with caution, considering the nature of this study (in vitro) and short period of investigation. Moreover, a simple environment (single-species biofilm) was used to evaluate biofilm formation of Candida regardless of the host factors of the oral cavity.

\section{Conclusions}

Within the limitations of this in vitro study it is possible to conclude that Plantago australis Lam. demonstrated promising antimicrobial activity, as it was similar to sodium perborate. Silicone based denture liner seems to be the best option to reline prostheses presenting lower microbial counts.

\section{Resumo}

Objetivos: os objetivos deste estudo foram avaliar a atividade antimicrobiana e o efeito nas propriedades mecânicas do uso de limpadores de prótese e do fitoterápico Plantago australis Lam. em dois reembasadores de prótese. Materiais e método: amostras de materiais à base de acrílico e de silicone foram submetidas à formação de biofilme, usando-se placas de cultura de células de 24 poços para formação de C. albicans por 1,7 e 14 dias. Os espécimes foram submetidos aos seguintes tratamentos: água destilada, hipoclorito de sódio 0,5\%, perborato de sódio e Plantago australis Lam. As seguintes propriedades foram analisadas: sorção e solubilidade, rugosidade de superfície e microscopia eletrônica de varredura (MEV). Resultados: a análise de variância de três vias mostrou uma diferença estatisticamente significante entre materiais $(p<0.001)$ com o material à base de resina apresentando maior rugosidade de superfície. Teste $t$ pareado não mostrou diferença de mensurações antes e após os tratamentos. Teste $t$ não mostrou diferença estatisticamente significante para sorção $(p=0,364)$ e solubilidade $(p=0,278)$ para ambos reembasadores. $A$ análise de MEV revelou uma topografia de superfície mais irregular nos reembasadores a base de resina após tratamento com hipoclorito de sódio. Contagens de C. 
albicans foram iguais para perborato de sódio, Plantago australis Lam. e água destilada, enquanto hipoclorito de sódio mostrou menos contagens $(p<0,05)$. Conclusões: com esses dados, conclui-se que hipoclorito de sódio 0,5\% foi o mais efetivo limpador de prótese.

Palavras-chave: Dentaduras. Limpadores de dentaduras. Candida albicans.

\section{References}

1. Pereira-Cenci T, Del Bel Cury AA, Crielaard W, Ten Cate JM. Development of Candida-associated denture stomatitis: new insights. J Appl Oral Sci 2008; 16(2):86-94.

2. Wright PS. The success and failure of denture soft-lining materials in clinical use. J Dent 1984; 12(4):319-27.

3. Gornitsky M, Paradis II, Landaverde G, Malo AM, Velly AM. A clinical and microbiological evaluation of denture cleansers for geriatric patients in long-term care institutions. J Can Dent Assoc 2002; 68(1):39-45.

4. Garcia RM, Leon BT, Oliveira VB, Del Bel Cury AA. Effect of a denture cleanser on weight, surface roughness, and tensile bond strength of two resilient denture liners. J Prosthet Dent 2003; 89(5):489-94.

5. Boscato N, Radavelli A, Faccio D, Loguercio AD. Biofilm formation of Candida albicans on the surface of a soft denturelining material. Gerodontology 2009; 26(3):210-3.

6. Casaroto AR, Lara VS. Phytomedicines for Candida-associated denture stomatitis. Fitoterapia 2010; 81(5):323-8.

7. Burkart A. Flora Ilustrada de Entre Rios (Argentina). 6. ed. Buenos Aires:Colección Cientifica del I.N.T.A; 1979.

8. Palmeiro NMS, Almeida CE, Ghedini PC, Goulart LS, Baldis serotto B. Analgesic and anti-inflammatory properties of Plantago australis hydroalcoholic extract. Acta Farm Bonaerense 2002; 21(2):89-92.

9. Andrade-Cetto A. Ethnobotanical study of the medicinal plants from Tlanchinol, Hidalgo, Mexico. J Ethnopharmacol 2009; 122(1):163-71.

10. Luo G, Samaranayake LP. Candida glabrata, an emerging fungal pathogen, exhibits superior relative cell surface hydrophobicity and adhesion to denture acrylic surfaces compared with Candida albicans. APMIS 2002; 110(9):601-10.

11. de Moraes AP, Barwaldt CK, Nunes TZ, Sarkis-Onofre R, Ogliari FA, Boscato N, et al. Effect of triazine derivative added to denture materials on a microcosm biofilm model. J Biomed Mater Res B Appl Biomater 2012; 100(5):1328-33.

12. da Silva FC, Kimpara ET, Mancini MN, Balducci I, Jorge AO, Koga-Ito CY. Effectiveness of six different disinfectants on removing five microbial species and effects on the topographic characteristics of acrylic resin. J Prosthodont 2008; 17(8):627-33.

13. Nikawa H, Jin C, Makihira S, Egusa H, Hamada T, Kumagai $\mathrm{H}$. Biofilm formation of Candida albicans on the surfaces of deteriorated soft denture lining materials caused by denture cleansers in vitro. J Oral Rehabil 2003; 30(3):243-50.

14. Brozek R, Koczorowski R, Rogalewicz R, Voelkel A, Czarnecka B, Nicholson JW. Effect of denture cleansers on chemical and mechanical behavior of selected soft lining materials. Dent Mater 2011; 27(3):281-90.

15. Webb BC, Thomas CJ, Willcox MD, Harty DW, Knox KW. Candida-associated denture stomatitis. Aetiology and management: a review. Part 1. Factors influencing distribution of Candida species in the oral cavity. Aust Dent J 1998; 43(1):45-50.
16. Ferreira MA, Pereira-Cenci T, Rodrigues de Vasconcelos LM, Rodrigues-Garcia RC, Del Bel Cury AA. Efficacy of denture cleansers on denture liners contaminated with Candida species. Clin Oral Investig 2009; 13(2):237-42.

17. Pereira-Cenci T, da Silva WJ, Cenci MS, Cury AA. Temporal changes of denture plaque microbiologic composition evaluated in situ. Int J Prosthodont 2010; 23(3):239-42.

18. Kawano F, Dootz ER, Koran A, 3rd, Craig RG. Sorption and solubility of 12 soft denture liners. J Prosthet Dent 1994; 72(4):393-8.

19. Mutluay MM, Oguz S, Floystrand F, Saxegaard E, Dogan A, Bek B, et al. A prospective study on the clinical performance of polysiloxane soft liners: one-year results. Dent Mater J 2008; 27(3):440-7.

\section{Corresponding author:}

Prof. Noéli Boscato

School of Dentistry, Federal University of Pelotas

Rua Gonçalves Chaves 457, room 508

96015-560 Pelotas-RS, Brazil

Fone: 533225.6741 ext. 135

E-mail: noeliboscato@gmail.com

Recebido: 24/03/2014. Aceito: 06 /08/2014. 